\title{
Women's Farming Collectives: An Inquiry into the Resource Sharing Patterns across 3 Districts of Maharashtra to Provide Evidence for Sustainable Environmental Collective Action ${ }^{\mathrm{i}}$
}

\author{
Roshan Rathod $^{\mathrm{ii}}$ \\ Society for Promoting Participatory Ecosystem Management (SOPPPECOM), India
}

Copyright $\bigcirc 2018$ by authors, all rights reserved. Authors agree that this article remains permanently open access under the terms of the Creative Commons Attribution License 4.0 International License

\begin{abstract}
India is an agrarian country where, $80 \%$ of its agricultural labour is performed by women. Yet, she is not recognized as a farmer as being a farmer is synonymous to owning agricultural land. The land ownership statistics are obscure for women with only $12 \%$ of the operational land holding in India and $15 \%$ in the state of Maharashtra in particular. This study through its in depth understanding of women's farming collectives in the 3 districts of Ratnagiri, Sindhudurg and Beed in the state of Maharashtra provides insights in the functioning, resource sharing patterns with respect to land, labour, seeds and water, and puts forward a case for collective action and its benefits in terms of accessing resources where absence of land holding for women farmers exists. The study in the larger context highlights the interesting experiments that women themselves are engaging in and growing organic produce while creating a collective space which is an economic as well as a social space. Ecological sustainability, economic democracy and social well-being are manifested in the nature of these collectives themselves. The main aim of this work is to ensure recognition of women as farmers and provide a platform for them to access land rights collectively.
\end{abstract}

Keywords Collective Action, Gender, Natural Resource Management, Organic Farming and Democracy

\section{Introduction}

Women represent more than $40 \%$ of the global labour force and $43 \%$ of the global agricultural labour force. The NSSO (2009-10) shows that in India, 79\% of women continue to be engaged in agriculture and allied activities as against only $63 \%$ of men (Dand et al, 2015)[1].It is significant to notice that women even though barely own a national average of only $12 \%$ of operational land holding have over the years been extensively involved in different kinds of farming operations such as the production of major grains and millers, land preparation, seed selection, sowing, applying manure, fertilizer and pesticide, weeding, transplanting, threshing, winnowing and harvesting. But despite this increased involvement in the farming activities, women are as close to ignored in the decision making process of farming. Land ownership is the link to achieving economic as well as social standing in society. Land acts as a metaphor she says, for power, wealth and status and in the context of farmers a necessity to even access various other extension services (Velayudhan, 2012) [2]. But unfortunately women, economically and socially, aren't considered as equals to access this ownership over resources. It is in this context, where deteriorating agricultural conditions and an agrarian crisis of sorts, the initiatives which women farmers are taking collectively, need to be studied and understood. Collective institutions act as strongholds for the purpose of natural resource management. Although it is gendered in itself to believe that women are inherently more conservationist than men, the distinctness of women's social networks symbolizing prior experience of successful cooperation, their higher dependence on these networks (as also on the commons such as water, forests etc. in general), and their potentially greater group homogeneity relative to men, could provide an important (and largely ignored) basis for organising sustainable environmental collective action. In order to discuss, theorize and make evident sustainable collective action for the purpose of natural resource management, it is of great significance to understand why the role of 'gender' is important. 


\section{Background and Rationale}

\subsection{Theoretical Literature}

Literature on collective action and its relation to natural resources in the environment has evolved over the years and follows a trajectory. The dictionary of Sociology defines collective action as the action taken by a group (either directly or on its behalf through an organization) in pursuit of members' perceived shared interests' (Gordon and Scott, 2009) [3]. Over the years more and more attributes have been added to the definition of collective action and collectives that emerge out of collective action. Ostrom very appropriately contributes to the theory of collective action by expanding its domain to informal groups as well where short term or long term collective associations are established by local networks and local groups of people (Vanni, 2014) [4]. While talking about collective action and collectives, Ostrom and others stress on the institutional support (government, NGO or any other external agency) that has provided the necessary push to the collective to emerge as outcomes, especially in agriculture (Uetake, 2013) [5]. Vanni also highlights how collective action in relation to natural resources and in the scope of this study of agriculture especially, through works of Baland (1996) [6], Wade (1987) [7] and Ostrom (1990) [8], certain specific factors are necessary to be taken into account. Arun Agarwal (2001) [9] categorizes them as follows:

1. Resource system characteristics

2. Group characteristics

3. Institutional arrangements

4. External environment

These characteristics enable the collectives to be studied and understood in a more in-depth way as they incorporate key issues to be looked at. Bina Agarwal (2010)[10] in one of her articles on contextualizing collectives in the agricultural production space, while looking at similar categories, arguing for a group approach to alleviating poverty through investing in agriculture by forming agriculture collectives of the poor, and in this case, poor women farmers. She emphasizes on the need to revisit collectives which are now bottom up, voluntary, socio-economically homogenous, participatory in decision making and small sized with a human rights approach. She puts forward a case stating that collective action as opposed to individual approach can work better in improving the well-being of the poor. She stresses on bottom up collectives where women are more subjects than objects of the course of action that they take.

\subsection{Other Literature on Supporting Frameworks and Tools}

The Women Empowerment in Agriculture index, which was developed collaboratively by The United States Agency for International Development, International Food Policy Research Institute, and Oxford Poverty and Human Development Initiative, is a tool which aims to measure the empowerment, the agency and the inclusion of women in the agriculture sector [11]. Women play a crucial part in the field of agriculture across the world. This is where the WEAI comes in as a useful tool. It measures the roles and extent of women's engagement in the agriculture sector in five domains namely decisions about agricultural production, access to and decision making power over productive resources, control over use of income, leadership in the community, and time use. This tool enables the researcher to understand the extent to which a woman farmer owns her resources, accesses resources, her decision making power in the production of agriculture as well as her overall situation with respect to agriculture. The most interesting aspect of this index is that it highlights and brings to the forefront an array of domains that do exist to showcase women's empowerment in agriculture. But although it looks at all these aspects, it does fail to recognize the relationship that women share with the environment around them and take into consideration the feminist perspective while understanding the 'why' of the indicators. And hence other frameworks have also been used for this study and have contributed to learning other aspects of this relationship. Though the approach is narrow in terms of quantifying empowerment which is not always possible, it does provide a guiding point in order to collect qualitative information.

When one talks about women in agriculture and women as farmers, it is of significance that women are not regarded as an isolated category attributed with homogeneity but placed within a framework where gender roles with respect to ecological, political and social relations are studied. Feminist Political Ecology, within a single framework brings in the feminist perspective with respect to the above mentioned relations (Vanni, 2014) [4]. According to Rocheleau (1996) [12] and others, feminist political ecology provides valuable framework in analyzing stories and experiences of women in relation to ecology across the world. It identifies various concepts, such as gender-based asymmetrical entitlements where gendered rights over resources are looked upon, the value of local (read traditional knowledge) not only because of its intrinsic worth but because of its contribution to sustaining environments, and notions of gendered spaces, especially market spaces and collective struggles. This framework which gives a holistic understanding of women and their relationship with the environment isn't a simplistic approach to merely adding gender to the analysis. It first realizes that differences of class, caste, ethnicities, sex exist with differential access to natural resources while accepting those pluralities as well.

While feminist political ecology gives us a deep insight 
into understanding women's relationship with the environment and placing them within the political context, there are certain attributes which are unable to look at ecological sustainability and economic democracy, which within the context of understanding women farmers is crucial. The Radical Ecological Democracy framework comes in this place and addresses this gap while keeping democracy at its epicenter and addressing attributes like ecological sustainability, economic democracy and social justice and well-being. Ashish Kothari (2014) [13], through this framework, gives great value to the concept of 'Swaraj', which is translated to be freedom. This alternatives framework talks about collective commons and solidarity with individual freedoms, where both common custodianship as well as individual freedoms is respected. The fulcrum of collectives here is sharing resources and relationships of caring.

The larger literature on collective action with supporting guidelines and concepts from the other frameworks \& indices pave way for further scope for research in formulating a case for women's farming collectives in the state of Maharashtra in a data deficit environment.

\subsection{Empirical Literature}

To provide testimony to the literature that exists in theory on collective action and especially on women's farming collectives in other regions like the south and north of the country, a case is attempted to be put forward not for exact replication of the model but the underlying philosophy of collective action.

\subsubsection{The Women's Collective of Tamil Nadu}

The Women's Collective of Tamil Nadu over the years of its sustained efforts is now known among not only environment circles but across the country as to how women's farming collective can and are fighting the green revolution technology. The 150,000-strong women's collective led by Sheelu Francis across 16 districts in the state of Tamil Nadu is working with the aim of improvement and water and food security, while also reviving and preserving the local environment and empowering women farmers. By forming groups of 10 women each and then collectively engaging in farming by leasing land for a period of three years and sharing $1 / 3$ of the crop with the land owner as payment (area of the land is decided by members themselves), the collective promotes sharing of resources and thus sharing of expenditure and democratic forms of decision making. The Collective has encouraged women to grow millets and revive traditional varieties of crops which are rich in nutrients and suitable to local and cultural context. The social collective network helps women to maintain a certain level of food security through collective farming and sangams (confluences) - lowering risks of absolute poverty with improved yields due to organic farming [14].

\subsubsection{Maati Collective}

Situated in the region of Munsiyari of Pithoragarh district of Uttarakhand is this autonomous collective of women called Maati. Maati is originally translated into soil which is also their primary area of concern. Though Maati primarily started as a response to the violence that women were facing due to excessive alcohol consumption in the area, it has now moved forward by way of ensuring sustainable livelihood options for women with keeping in mind ecological sustainability as well. Their aim is to empower women in their capacities as producers of food and other related activities and make farming a viable long term option. One of the most interesting aspects about this collective is that the preservation of traditional varieties of seeds is not in a bank but by engaging in seed exchanges with members of the collective. As women are not landowners, they aren't recognized as farmers and thus fall short of accessing financial support as well as technical inputs that the state may provide them with. Hence, Maati has mobilized these women to form self-help groups and now collecting, procuring and sharing of seeds are done within these groups which thus help in maintaining soil fertility and revitalizing traditional knowledge systems of maintaining productivity [15].

\subsubsection{Deccan Development Society}

The Deccan Development Society which started almost 25 years ago is an organization working towards collectivizing poor women, primarily Dalit women into sanghams (voluntary village level associations of the poor) in Medak district of Andhra Pradesh. The vision that the society had in mind initially was the simple provision of sustenance needs of the sangham members but now this movement has evolved into a tool of empowerment for poor, Dalit, women farmers with a goal of working towards the following autonomies [16].

- Autonomy over food production

- Autonomy over seeds

- Autonomy over natural resources

- Autonomous markets

- Autonomous media

\subsection{The Situation in Maharashtra}

The state of Maharashtra recorded 82 percent of the population with a per capita income below not only the state but also the national average and according to the Planning Commission Maharashtra State report. In these districts, agriculture is the main economic activity. In Maharashtra, with the drought hitting for three consecutive years accompanied with declining ground water tables, decreasing soil fertility due to heavy chemical farming and increasing indebtedness of the 
farmers, the situation is deteriorating. Dire socio-economic conditions have created a culture of migration, especially men migrating to neighboring cities in search of employment, leaving the women behind. There is an increase in the feminization of agricultural labour rather than agriculture itself where women are engaging in more than 80 percent of the labour performed on the farms.

It is also important to note that Maharashtra is the state with the highest production of sugarcane and highest amount of land under cultivation for sugar as well. This crop is extensively cultivated in the Marathwada region of Maharashtra. Sugarcane is an extremely water as well as chemical intensive crop. This is also true for cotton cultivated mainly in the region of Vidarbha. The over emphasis on the cash crops, feminization of agricultural labour and fluctuating climatic conditions, is making farming as a means of livelihood vulnerable, and even more the women farmers. Despite this vulnerability, there are interesting experiments that women farmers are coming together and engaging in. Groups are coming together, sharing resources like land, water and seed; sharing spaces and engaging in organic farming and reviving traditional knowledge systems. The paucity of literature on these initiatives that women farmers are part provides an impetus to engage in this study and to contribute to the larger literature on collective action. It is also to propose for a collective model for women farmers to have access to and control over resources through collective bargaining.

\section{Objectives and Methodology}

\section{Aim}

To assess the potential of women's farming collectives as platforms in accessing land and other natural resources in resource scarce areas and enabling sustained livelihood options for them, while contributing to the literature on collective action through field experiences.

\section{Objectives}

1. To map women's farming collectives and get an in depth understanding of their resource ownership and resource sharing patterns

2. To understand the modes of functioning/operation of women's farming collectives in the resource scarce state of Maharashtra across 3 districts

3. To understand the economic, ecological and social implications of women's farming collectives in the study area.

4. To suggest practical recommendations for the promotion of women's farming collectives across districts.

\section{Methodology}

Caroline Ramazanoglu in her book Feminist Methodology writes how methodologies specify how social investigation should be approached by linking a particular ontology and a particular epistemology in providing rules that specify how to produce valid knowledge of social reality (Krook, 2007)[17]. In this case (of the study) understanding that gender as a concept is not natural but a social construct and getting into creating knowledge around that is important. Krook explains how the methods which are techniques and procedures are used for exploring social reality and producing evidence that we use to obtain the knowledge aren't feminist in nature but the methodology is. And in fact there isn't one, but different kinds of feminist methodologies. Feminist methodologies are shaped by feminist theory, politics and ethics; and are grounded in women's experiences. The type of methodology adopted for this study was the 'participatory action research' methodology. This type of a methodology involves the research subject to become a part of the research process in order to achieve political goals. In my understanding, the researcher and the research subject need to become a part of each other's every-day and participate in the process of research together.

For any study, especially an exploratory one like this, at the epicenter lay its methods and methodology. Hence, a detailed wording of the methodology is extremely crucial and needed. Before the drafting of the questionnaire, secondary literature was reviewed and the questions were based on various frameworks. The domain areas with various indicators were as follows:

1. Motivation behind the collective

2. Socio-economic profiles of the members of the collective

3. Resource ownership and sharing patterns - Land, Water, Seeds, Labour

4. Economic and Production Democracy

5. Ecological Sustainability

The method of primary data collection identified to be used was the ethnographic method. Ethnography is a holistic approach to study cultural systems. It is a process of discovery, of making references and continuing inquiries in an attempt to achieve validity. And the most important aspect of ethnography is that it is an open emergent learning system where the researcher has a certain space of freedom as opposed to that of a rigid investigative approach (Whitehead, 2005) [18]. The used tools were semi-structured interviews, participant observations (women working in the farms), informal discussions and focused group discussions.

\section{Sampling Technique}

The sampling technique used in this study was 
convenience sampling. Convenience sampling (also known as Haphazard Sampling or Accidental Sampling) is a type of nonprobability or non-random sampling where members of the target population meet certain practical criteria, such as easy accessibility, geographical proximity, availability at a given time, or the willingness to participate are included for the purpose of the study (Etikan, Musa, \& Sunus, 2016) [19].

It also needs to be noted that this study has included one collective that cultivated plots individually. The reason why collective was also a part of the study was that they shared a collective market space. The study is attempting to explore various different forms that collectives can take and hence it goes beyond the narrow definition on collectives.

\section{Study Area}

The study area was also chosen as per convenience of the researcher and the researched, as mentioned above. During the regional meetings, groups from Ratnagiri, Sindhudurg and Beed districts were identified for the study.

\section{Ratnagiri}

Ratnagiri is one of 36 districts of the state of Maharashtra situated in the Konkan region. With a total population of 1,612,672, the district is divided into 9 tehsils. One of the tehsils (taluka) is Lanjha of which the village Devdhe was selected for the study.

Devdhe is a medium size village located in Lanjha of Ratnagiri district, Maharashtra with total 291 families residing. The women's farming collective that was studied here was the 'Radha Krishna Swayam Sahayata Bachat Gat', Harmalewadi.

The second village where another women's collective was studied was Kondiye. Kondye is a medium size village located in Lanja of Ratnagiri district, Maharashtra with total 192 families residing. The name of the collective here is Mauli Swayam Sahayta Bachta Gat, Paliwadi, Kondiye.

Both the above mentioned collectives have been formed and provided handholding support through Heritage Culture Art and Education Development Society which was founded by Santosh Kamble in the year 1994.

\section{Sindhudurg}

Sindhudurg is an administrative district in the state of Maharashtra and located in the Konkan Division. The district has 8 Tehsils and the headquarters are located at Oros. According to 2011 census, Sindhudurg is the least populous districts of the state with a population of 849,651 individuals. The Taluka under which the study was conducted is Kankavali which is a central town in the district of Sindhudurg. The village where the women's farming collective was studied was Tiware village which is situated about $24 \mathrm{kms}$ from Kankavali. The village of Tiware has a total of 222 families according to Census 2011 and a total population of 942 individuals (Census, 2011)

The name of the collective was - Bharari Swayam Shayata Bachat Gat, Tiware. This SHG has been formed through the sustained efforts of MAVIM which stands for Mahila Arthik Vikas Mahamandal. MAVIM is the State Women's Development Corporation of Government of Maharashtra, established on the 24th February, 1975 on the occasion of International Women's year and a Nodal agency by Government of Maharashtra on 20th January 2003 to implement various women empowerment program through Self Help Groups (SHGs).

\section{Beed}

Beed is an administrative district in the Aurangabad division of the state of Maharashtra in the region of Marathwada, Beed. According to Census 2011, the population of Beed was 2,585,962. Beed district in total has 11 Tehsils. Beed provides one of the largest numbers of laborers in India, especially in terms of sugarcane cutting.

The taluka (tehsil) under which the study was conducted, was Ambajogai. Ambajogai city has a municipal council, Tehsil and subdivision in Beed district. The population of Ambajogai is 74,844 according to Census 2011.

The women's farming collective that was studied was located in the village of Sangaon. Sangaon is located about $22 \mathrm{~km}$ from the main market in Ambajogai.

The organization that provided extensive support during this study was Ankur Pratishthan and Sanshodhan Sanstha. Ankur Pratishthan and Sanshodhan Sanstha is a registered not for profit organization in Beed, Maharashtra. It was in 2003 that it started its work in the area of organic farming. Under a project initiated by the Institute for Integrated Rural Development (IIRD), Aurangabad, Ankur ventured into the space of organic farming by reaching out to farmers in adjoining villages. Since the inception of the program, Ankur has been able to reach out to almost 3000 farmers, men and women alike, spanning 19 to 20 villages.

\section{Results and Discussion}

Before the detailed analysis of the collectives and its members being discussed, it is important to mention that these collectives were formed under the SHG model. The SHG model which stands for Self-Help-Group model. SHGs are "membership-based organizations", i.e. organizations whose members provide each other with mutual support while attempting to achieve collective objectives through community action (Chen, Jhabvala et al. 2007) [20]. They usually consist of 10 to 20 women from socially and economically homogeneous backgrounds, 
poor backgrounds, and these groups are centred around savings, accessing institutional credit and on a productive activity, a means of livelihood which will enable with securing livelihood options for themselves. The ultimate aim is to be able to uplift their social, economic and political status at a household as well as a community level. Bina Agarwal (2010)[10] in her work on collectives describes them (as mentioned above in the paper) as small, socio-economically homogenous, voluntary groups with participative decision making at its core. The collectives studied as a part of this research are small, socio-economically homogenous groups of women where decisions related to all aspects are taken at a group level by all.

The findings from the field work for each collective are not being mentioned separately but together under different resources that were shared, the nature of the collectives, and democracy over inputs as well as outcomes of production and their overall sustainability

Before going into the details of the findings, it is important to give a profile of the women of these collectives as a context can then be built. These profiles are given for all women combined to give a general overview of the women and later findings would be specific to the collectives.

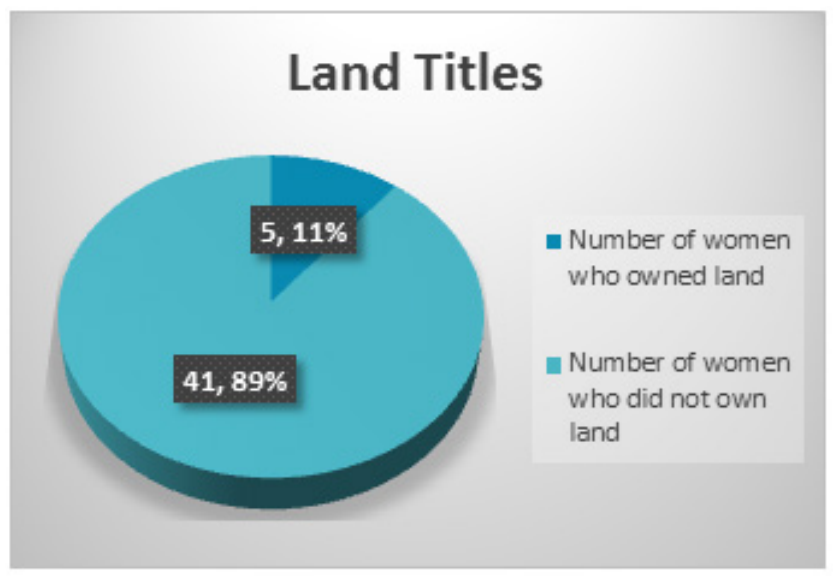

Figure 1. Profile of the women

Out of the 46 women that the researcher spoke to, only 5 women had their names on the land deeds of their household land holdings. Here household landholdings refer to agriculture land that the household together owns. But unfortunately in the patriarchal set up the land in always in the name of the husband, father-in-law, brother-in-law or son of the family. It is also important to note that out of the 5 women mentioned here who have their name on the land deed, 3 are widows where the land was transferred to their names after the passing away of their husbands, as under the law. Hence their names on the document weren't added voluntarily. An astonishing 41 women had absolutely no property rights neither from their natal side nor the in-laws.

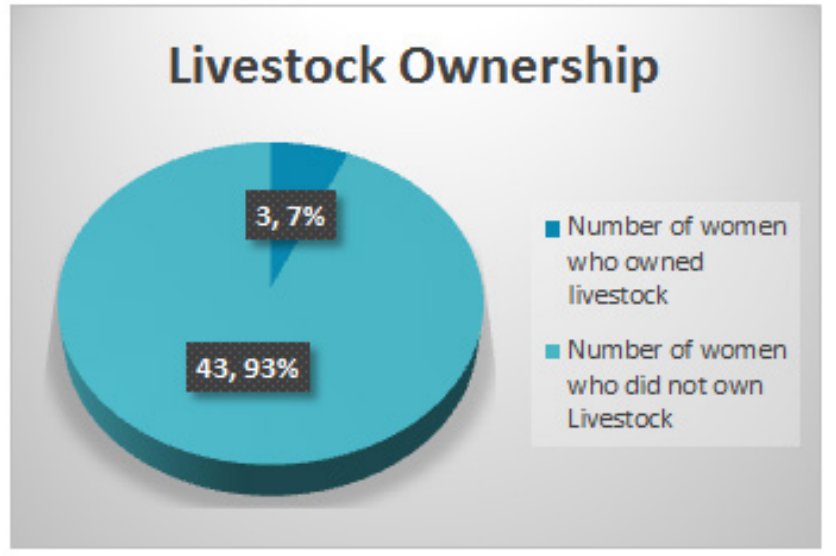

Figure 2. Livestock ownership of women

Livestock are domesticated animals raised in agricultural settings and they are used for food, fiber and labour. In the context of this study, they are studied as assets owned. Though there are no specific laws that exist in terms of livestock ownership or there is a concept of ownership of the livestock with an individual member or whether it is the household that really owns it, one can see the numbers speak for themselves here. In this case, the researcher has attributed criteria like say in the sale of the livestock, buying of additional livestock and decisions pertaining which breed or which species to buy to the 'ownership' of the livestock. From that point of view, only 3 women said that they had the ownership of the livestock which were the same widows mentioned earlier.

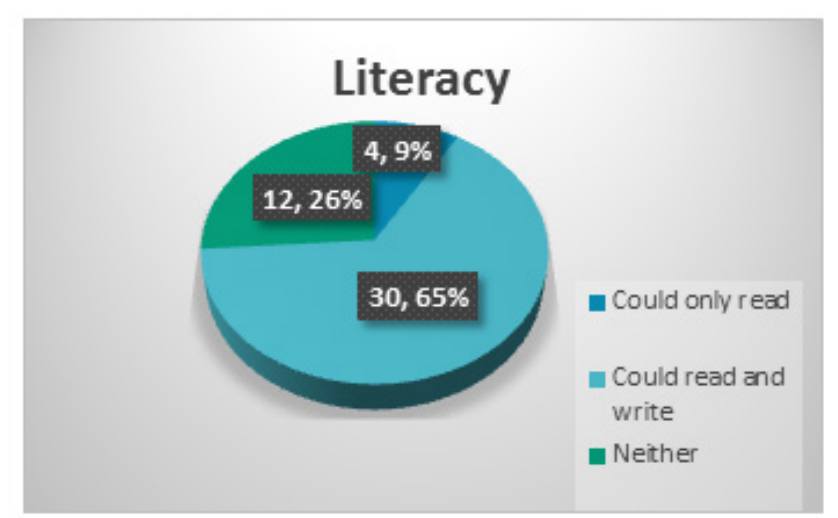

Figure 3. Literacy rate of women

Women of the collectives are to maintain their books of accounts and keep a record of their expenses and incomes in order to share the profits. For this a certain level of reading and writing skills are required. Out of the 46 women, 30 women which is a good $65 \%$ of the total could read and write.

The women of the collectives came from varied ages, from young to old. 14 women of the 46 were in the age bracket 31-40 whereas 6 were from the age bracket of 21-30 years. The maximum number of women came from the ages of 41-50. But overall women from all ages were a 
part of these collectives.

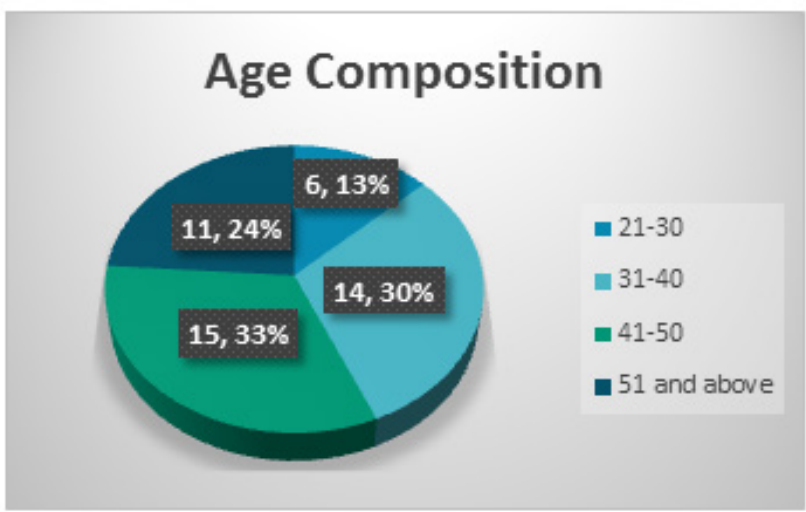

Figure 4. Age composition of women

\section{- $\quad$ Nature of the collective}

All the 4 collectives studied practiced cultivation of organic vegetables. Here the term 'Organic' refers to the inputs that were going into the production process. Also there was an omission of using chemical fertilizers, insecticides as well as GM or hybrid seeds in the process of production of the vegetables. It is also important to note that although 3 out of the 4 collectives engaged in physically coming together and farming on a said piece of plot, one collective practiced individual farming on their own plots. But the reason to call them a collective is as they shared the same market space in order to sell their produce. - REWRITE

\section{- $\quad$ Resource sharing patterns}

\section{Land}

There were different land use patterns that were observed in the study:

Leased Land: One collective engaged in collectively farming on a leased plot of land, for which they had a legal bond paper as well. The terms of contract were decided by both the parties and the collective was to pay Rs. 200 per month for a period of 2 years to the owner of the land. Along with this leased plot of land, they also engaged in farming on a member's plot (which was owned by her household) on a rotational basis.

Oral Agreements: One collective farmed on member's plot of land. There was no rent paid to the member for the use of the land. This contract was an oral contract based on mutual understanding between the member and others of the collective. This was carried on a rotational basis, too .i.e. each year a different member's land was taken under collective cultivation.

Third Party private property: One collective engaged in cultivating over a third person's private property. There was no written agreement between the collective and the owner of the land. This land belonged to an individual residing in a different city, who had undertaken cashew plantation on that piece of land. Since the cashew plantation was in its first year of production, there was a lot of space that was present between two cashew trees. It was the space between them in which the organic vegetables were grown. No rent was paid to the owner of the land, but a certain part of the produce was shared with the owner whenever he visited the land. This collective was also responsible to water the cashew plantation from time to time.

Individual Plots of Land: One collective did not engage in the collective farming on a single piece of land but engaged in cultivating on their individual pieces of land. Here since the ownership of the land belonged to the household whom the woman of the collective belonged to, there was no need of a contract whether in oral or written form.

\section{Water}

Each collective had access to a private bore which belonged to a member of the collective. The cost of water which was basically the cost of electricity used to draw the water through an electric pump into the field was shared as input cost by all members of the collective. It was accounted as a collective expense and maintained in the books as a cost incurred to the collective. Water is the scarce resource. Sharing it between members was one of the only ways to ensure water supply for cultivation.

\section{Seeds}

All the collectives used only organic seeds for cultivation of the vegetables. The most interesting aspect of these collectives was that almost all of them engaged in seeds exchange with other non-members of the village and in case of individual farmers, between the members of the same collectives. Since the collective at Devdhe has been functioning since the past 6 years, they have been saving their own seeds and use only those seeds. The collective that is now only in their first year of functioning hasn't been able to save seeds but have bought seeds from organic stores recognized by the government. They plan to save seeds from next year onwards.

\section{Labour}

Collectives that cultivated together on a piece of land shared labour. They segregated duties and worked together. Only 1 collective accounted for labour costs as they paid wages to the members who worked on piece of land as not all women worked on the farm at the same time. Family labour was also used in one collective where exchange of labour between extended families during harvest season existed. Men's labour was used for ploughing purposes across all collectives.

\section{- $\quad$ Market - Access and Control}

The most important aspect was the sharing of the 
economic space for these collectives. For the collective that farmed individually, they came together on a weekly basis in the local market to sell their organic produce. It was spectacular to see that this weekly bazaar consisted of almost 80 percent of women sellers. Earlier this market space was only for the organic produce but slowly it had been taken over by the chemically producing farmers and others. Because it is a public space, right over that space cannot be asserted by only the organic farmers. Women were the ones who would transport the produce as well as sell it. As for the other collectives, produce was sold on a rotational basis by member of the group in the local village market itself. One group even put up stalls of their produce at various events outside of their village.

\section{- $\quad$ Profit Sharing Norms}

For all three collectives that cultivated the vegetables together on a collective piece of land, profits were shared equally. The profits were calculated after all the deductions in terms of expenses were accounted for. What was interesting to note was that the profit sharing was not directly proportional to the labour inputs by the members. This meant that all members received an equal share of the profit irrespective of their contributions to the agricultural output. In one collective, there were two women who had recently undergone different medical procedures which restricted their contributions in terms of labour towards the process of cultivation. The other members of the collective understood this and delegated less labour intensive activities to these members. As for the collective that engaged in individual farming, all the profits made belonged to the individual women farmers. There was no sharing of profits in that case as all input costs along with labour were borne individually by the farmers.

\section{- Decision making process}

Decision making is a crucial component of these collectives when different individuals come together on one common platform and many opinions co-exist. In the context of these farming collectives, decision making was a democratic process. All decisions pertaining to what to grow, when to grow, delegation of responsibilities, when to sell, where to sell and the division of profits, were decided by all the members of the group. They held regular meetings of the collectives where all norms were democratically decided upon.

\section{- Economic, Ecological and Social Implications of the collective:}

\section{Economic}

The women of the collective decided the price that the produce would be sold at. They all had complete control over the earnings that they made out of the sale of the organic vegetables. More than $30 \%$ of their earnings were spent on the welfare of the children in terms of education, clothing and food. Approximately $30 \%$ was utilized for day to day expenditure in the household, $20 \%$ was saved by them in either their bank account or in chit funds and the rest was what they called 'their own income' which meant they sometimes spent the money on themselves buying personal items.

\section{Ecological}

These collectives whether they cultivated individually or collectively, all undertook organic production of vegetables. This meant that all the inputs right from seeds to fertilizers were organic i.e. chemical free. In the short run, the effects of this on the ecosystem are not almost sudden, but in the long run they can be felt. The fodder which was being fed to the cattle was in turn now also organic in nature which was better for the health of the cattle. Natural and locally available inputs like neem, ginger, garlic etc. were used for making organic manure and bio-pesticides.

\section{Social}

The women from the collectives said that after the initiation of the collective, their self-confidence has increased not only in the group but also within the household. There were women in the collectives who, for the first time, had gone out of the village to sell their produce. This has given them a sense of independence which for them is beyond the income that they earn. Women of the collective at Devdhe many a times even cook together and eat together and share their life with each other. According to them the collective has given them something very important, friendships and relationships for a lifetime.

The above mentioned findings regarding resource sharing patterns, market spaces and overall ecological, economic and social factors go beyond recognizing only land a resource for farming activities. There are different processes and resources that together form the larger process of farming and especially organic farming where inputs in terms of labour is extremely vital. The question we need to answer is -Do these findings enable the woman to recognize herself as a farmer? Can she assert her identity as a farmer?

\section{Discussion}

Through the findings at the field, it is evident that women are now accessing land at the collective level, which otherwise was a far off reality for many of them. Control over the decision making process, access to institutional credit and most important access to land as a resource is now helping them recognize themselves as farmers. But there are still many aspects of the findings, 
which do not find space in the larger literature which need to be highlighted.

Despite performing all the work, their ownership over land remains a big problem. Only one collective had entered into a legal contract on the land that they were cultivating on. The others were either happy with oral arrangements or scared of legal arrangements. This kind of action still restricted them to access many government schemes which are applicable to small and marginal farmers which are directly linked to ownership of land. Another significant aspect that many a time fails to find its place in literature is the accessibility of women to technology and technological advancements. Technology by itself isn't a negative term. But when technology ends up as a helping hand to compliment labour intensive activities, to reduce the drudgery involved in the activities, which in this case is reduction of drudgery for women farmers in performing agricultural activities, technology is vital and the keystone is that a socio-technical perspective on technology with a focus on gender where women need to be recognized not only as users of technology but also makers of the same demands attention.

Collectives as a concept definitely provide a space for these women to have a greater hold over their bargaining power but can they be regarded as means to provide ownership of resources for these women farmers?

Arun Agarwal (2001) [9] in his work on sustainable governance of resources brings together three important works by Ostrom (1990)[8], Wade (1994)[7] and Baland-Platteau (1996)[12] . As mentioned earlier, there is a synthesis of factors for collective action that these pioneers talk about. Uetake (2013) [5] brings together this synthesis as 4 major characteristics of successful collective action. The first is the characteristics of natural resources involved and the knowledge and predictability of these very resources. The second is the characteristics of the group involved with respect to group size and homogeneity. The third factor is the involved institutional arrangements, on one side would include locally devised and simple rules and, on the other side, they should rely on effective monitoring and sanction systems. The fourth factor pertains to the relationships of the locally situated groups, resource systems, and institutional arrangements with the external environment in the form of demographic changes, technology, markets, and different levels of governance.

The field findings and observations of the farming collectives represent all these four important factors. The natural resources in question here were land, labour, seeds, water and forests. All the groups had well defined boundaries with respect to land especially. Water resources such as the bore-well and dug wells that were used belonged to the members who 'owned' the land where the cultivation of organic vegetables took place. Traditional knowledge systems like using of organic inputs from locally available organic matter were used and an exchange of knowledge took place not only between the members of the same group but also with non-members in the village. This basically meant spreading the knowledge about the benefits of organic farming to the villagers as well as the end consumer buying the produce. The women farmers were aware of the water availability in their region and took up the cultivation of only those vegetables that required lesser amount of water as compared to other water-intensive crops and hence worked on the predictability of the natural resources in question.

With respect to the second factor of group characteristics, all groups were small sized which had the membership of 10-20 women from socio-economically homogenous backgrounds i.e. is the BPL category (Below Poverty Line). This acted as an extreme advantage when it came to decision making. As there was homogeneity in terms of social and economic identities of these women, power differences did not exist to a large extent. Democratic decision making is the key here and that can only happen when every member has an equal say in not only the final decision but in the process of decision making itself. When inequalities that are embedded in economic status with respect to income and caste and other social criteria are not stark, group dynamics function in a much smoother way. There is an absence of inherent inequalities and hence, the group functions better.

The third factor that deals with institutional arrangements with locally devised simple rules and effective monitoring and sanction systems reflects well with these collectives. All the groups had collectively in a democratic fashion formed the rules and norms of the group. This meant decisions with relation to what to grow, how to grow, where to sell and at what price to sell had the consent of every member of the group. The profit distribution norms were also set by the group itself which also meant when is the profit to be distributed to the members of the group and in what proportion. Monthly meetings which shared details of the produce sold till now, profits made and expenses incurred were testimony to the monitoring systems that the collectives had devised for themselves. They recorded almost $95 \%$ attendance for all the monthly group meetings.

The forth factor which deals with external environment and authorities both in terms of financial as well as non-financial support is a very significant factor for successful collective action. All the four collectives that were studied were provided guidance and support in terms of trainings for organic farming and bank linkages in order to access institutional credit services. Every member of every collective had access to monetary loans for the betterment of the livelihood source that they had chosen which in this case was organic farming. Market spaces and technology access are two key factors which can ensure sustained rights to livelihood. In the Feminist Political Ecology Framework, gendered spaces like the market denotes the patriarchal, power filled nature of the market spaces, provides restricted or supervised entry to women. 
Rajni Bakshi (2012) [21] in her work on market spaces follows the evolution and trajectory of the market from a weekly bazaar which revolved around human relationships and interactions to a more capitalist patriarchal set-up. But in the case of these collectives it was interesting to see how the weekly bazaars which had almost become absent still existed and more so were dominated by women both as sellers and buyers. Upon inquiring further, it was found that the vegetable market was more the space of the woman as this market space involved human interactions and where buyer engaged in bargaining the price with the sellers. As Umesh Lemte from Ankur Pratishthan puts forth, "Men cannot handle bargaining, they are unable to negotiate prices on a daily basis like this whether as a seller or a buyer. Hence you will always find only women coming and selling their vegetable produce here". Further probing on where were all the men then he said "Men sell cash crops. You will find them in the mandis not here. The volume of the transactions and hence the money is high there and they control those transactions".

The findings of the study also conform to various aspects of the Radical Ecological Democracy framework (Kothari, 2015) [22]. This evolving framework of governance is defined by the fact that each person and community has access to decision making processes and forums of relevance to them, and in which the decisions taken are infused with ecological and cultural sensitivity, and socio-economic equity (Kothari 2014)[23]. In terms of ecological sustainability, the study observed that the Collectives had been involved in the organic production of vegetables for the past 6 years and the members themselves had come to realise the benefits of this type of farming from the ecological point of view. They have observed for themselves how soil quality in terms of porosity has improved for them which have now led to vegetables demanding lesser amount of water for cultivation. The use of indigenous species of seeds and organic seeds is providing them not only with a better yield but also healthier food to consume for the families. Economic democracy and direct democracy stand strong with these collectives. Every individual has not only been involved in the final decisions pertaining to anything in the collective but also in the very process of decision making. Social capital, described by Bourdieu (1986)[24], is the sum of the resources, actual or virtual, that accrue to an individual or a group by virtue of possessing a durable network of more or less institutionalized relationships of mutual acquaintance and recognition', which acts as very strong push factor for these members and the mutual understanding that exists between them enables them not only to function in a better way but has ensured a social space for them to come together and even share life experiences. The women of the collectives have complete control over the earnings of the produce. Decisions regarding savings, expenditure and re-investment in the agricultural activities were made solely by the women.
It is increasingly recognized that the collective action of farmers and of other rural stakeholders may also play an important role in delivering public goods, non-commodity outputs and environmental services (Polman et al. 2010)[25].

\section{Study Recommendations}

This study at this stage is not aimed to make policy recommendations at the national level as yet. The main aim as mentioned above is to make a case for collective access to land as a resource for these collectives especially for women in ensuring a sustainable means to livelihood. Certain aspects of the institutional arrangements of land use patterns need to be relooked. For example:

1. Issue of land ownership and control over land: Groups of women who are engaging in alternatives in livelihood security should be given priority in terms of access to land in enabling them to assert their identity as farmers. An alternative mechanism could also be that of redistribution of 'wastelands', which can serve twin purposes of reclamation while becoming means of economic empowerment. An empty area of land, especially in or near a city, which is not used to grow crops or built on, or used in any way and/or a place, time or situation containing nothing positive or productive, or completely without a particular quality or activity (Shailesh, 2011)[26]. These degraded or rather neglected lands can be better utilized for cultivation purposes by providing access to these women collectives cultivating organically.

2. Recognition as farmers enables them to access various government schemes and extension services that are otherwise available to 'farmers'.

3. Another very significant recommendation is in terms of ensuring fair pricing to these women farmers who put in extra labour to produce organically. Technology can be used to their advantage as every single person most definitely owns a mobile phone. Collectives can use collective bargaining in price determination using technology and other methods as market access and market prices are inevitable realities of a sustainable means to livelihood options.

4. There is an immediate need to address the issue of lack of women friendly technology in agriculture. While the makers of technology are men, it is mostly the women who are the users of this technology in the agricultural fields. Their dependence on men for the use of physically labour intensive equipment is high. In order to be able to be completely independent as farmers, women 
need to be able to access user friendly technology. A socio-technical perspective in terms of women farmers needs to be considered.

\section{Limitations and Scope for Future Research}

It is important to note that this study was able to study only 4 collectives across 2 regions and 3 districts in the state of Maharashtra. No generalizations can be made on these findings. The nature of these collectives enabled the researcher to draw these particular findings. But in case the collectives were heterogeneous socio-economically or had a top down approach in decision making, these finding would not hold true. There is further scope of study in terms of understanding various other collectives across the state and the country as a whole and get an in depth insight into their functioning in terms of ecological, economic and social viability.

\section{Acknowledgements}

No study, no research or any other written document or otherwise that involves the efforts of so many people is complete without a simple thank you and acknowledging their contributions towards the work.

The first and foremost person I'd like to thank is Dr. Smriti Das who has not only been my internal supervisor through this study but an individual from whom I've learnt and grown in this area of work. Dr. Das's sense of direction has always made me think in ways beyond the linear patterns.

To Seema Kulkarni, my external supervisor from SOPPECOM, whose ideas, guidance and encouragement to learn new things, never ceased. Her support through this study has enabled a relationship beyond the scope of this study. Thank you for all that you've made me learn including your humility. A big thank you is also to Sneha Bhat from SOPPECOM and other staff members who were always ready to hear me out and my crazy, ambitious ideas at all points of time.

Ashish Kothari has being a constant support not only in this study but as a friend throughout. His alternative way of thinking enabled a great amount of innovativeness in the study and my life.

To Dr. Nandan Nawn for being one of the first ones to help me broaden my ways of thinking and pushing me to think beyond my comfort zone. His comments have always added value to my work and made me confident with my critiques.

This study would not have been possible without the support of my parents, who at all times took such keen interest in my area of work, supported the nature of this work and provided me with a space mentally and physically to think, learn and grow. My sisters never got bored of listening to my changing thoughts and my dog Sonu.

To my friends who since the beginning of TERI have had such interesting insights into the work we do and aim to do in the future. Silas, Bhavya, Sanjana, Bhargavi, Kalai, Pooja and Craig, thank you for being there and critiquing my work which helped me think and only get better.

When I say I saved the most important for the last, I mean it. This work in no way would have been possible without the women farmers and their families that hosted me. Sangeeta tai, Sujata tai, Santosh Kamble, the Gurav family and Pradnya especially who influenced my life in ways more than I'd imagined. Thank you for all the time as I know that is so difficult with the kind of work day that these women have, the love, the affection, the food, the insights and most importantly thank you for making me feel like a part of your collective. A sincere thank you to all the other members of the collective, the people of the villages of Devdhe, Tiware, Kondye and Sangaon. Acknowledgements to Ankur Pratishthan, Heritage Culture, Art and Education Development Society and MAVIM for making arrangements for this study and facilitating the process.

And the last thank you to all my classmates of the batch of 2014-2016 of MA Sustainable Development Practice of TERI University and the readers of this report for your time and valuable feedback.

This work is also dedicated to Dr Devendra Singh Chauhan who helped me make sound, logical arguments and trained me to be a better writer. I hope I make him proud. 


\section{Annexure 1}

\section{Questions}

General information about the collective

1. Name of the Collective

2. Number of women and their names with village

3. Age composition of the members

4. Active since when

5. Which is the external organization providing handholding support to them?

Socio Economic Profile of the women in the collective (material asset)

\begin{tabular}{|l|l|l|l|l|l|l|}
\hline Name & Land holding of family & Land in her name & Livestock & Water Equipment & Vehicles & Any other item defined as asset \\
\hline & & & & & & \\
\hline & & & & & & \\
\hline
\end{tabular}

1. Primary livelihood earning activity

2. Secondary livelihood earning activity

3. Number of family members

4. Education levels (formal)

5. Any of the women holding any other post in any village body like the panchayat?

\section{Motivation}

1. How did the collective start? Why did the collective start? Any specific reason like health or drought?

2. Was there any internal social movement or a training by an NGO or so that gave rise to the formation of the collective?

3. Is it an SHG model that is followed? Is it because of the SHG that was already formed, did the farming collective develop?

4. Was there resistance from the family members or villagers or anyone else while venturing into this activity?

\section{Nature of the collective}

1. Is it a crop based/age based/caste based collective?

2. Does it include only women or are men to a certain extent also a part of it?

3. What are the activities that the collective is engaged in?

4. Was farming an initial activity itself or came in later?

5. Do women practice farming on their separate individual plot of land or lease out a piece of land?

6. What is the type of farming that women engage in? Completely organic or a mix of organic and chemical based or only chemical?

7. What is the process of farming that they engage in?

8. How do they make their manure? Have they received training for that as well?

9. Which seeds do they use for cultivating their crops and vegetables?

10. Do they engage in seed saving practices?

11. Have they been able to revive any traditional crops through saving seeds?

12. Is there a concept of seed bank or seed sharing among the members? Are they parts ofany government scheme for encouraging seed conservation?

13. What are their water usage practices? Irrigation or rain-fed? Ask everyone?

14. What are the resource sharing practices that they engage in?

15. Mapping of water sources?

16. How are their needs for water met?

17. How much time do they spend in the field? Do they have any time for leisure activities? ( a daily clock activity)

\section{Production from farming:}

1. What are the inputs that go into their technique of farming?

2. Who decides what to grow?

3. Is it decided at the collective level or individually by farmers? By women themselves or men of the house? 


\section{Nature of Produce}

\begin{tabular}{|l|l|l|l|c|}
\hline Name of crop/Vegetable & Type - Organic/Traditional & Self-Consumption/Market Sale & Yield & Income \\
\hline & & & & \\
\hline & & & & \\
\hline
\end{tabular}

\section{Knowledge Management (Traditional as well as acquired knowledge)}

1. Were the women provided any training in farming practices by an external organization?

2. How often are these trainings conducted?

3. Do they feel that they are using traditional knowledge systems itself in their farming practices?

4. How much is the contribution of TK to their farming practice?

5. Do any cultural or spiritual practices that they follow still exist in relation to the activity of farming?

6. Do they share knowledge amongst not only each other but also non-members in the village who are farmers?

\section{Market Linkages}

1. How is the produce sold in the market?

2. How is the price of the produce decided in the market? Any power over that decision?

3. Are they all sold locally? Any export takes place? Was there any activity like exporting before?

4. Do they have a dedicated market space for themselves?

5. Do they feel that the market space has given them confidence to sell their produce?

6. Since the inception of their activity, has the market for their produce existed?

7. Do their husbands or another member of the family help in marketing the produce? In the out of the house activities, what is the level of their involvement?

8. Do they collect their produce together and sell or individually?

9. Have they ever tried to dictate prices in the market of their produce?

10. Who buys the produce? Only individuals? Or have they tried to tie up with anyone?

11. Has the quality of the produce been responsible for loyalty with customers?

\section{Sustainability Aspect:}

1. Economic Sustainability

1) How are they able to fund their activities?
2) Does the government provide any support either monetary or otherwise for the activity to sustain?

3) All in the form of loans (payable) or any grants that have also come by?

4) Do they access to institutional forms of credit?

5) What are the available institutional set ups promoting agriculture?

6) Colleges and its composition?

7) Do they make enough money for it to sustain on their own incomes?

8) Have they tried collectively to raise funds otherwise? Or approach the government in seeking funds through schemes?

9) Have they seen a rise in productivity levels? Absolute productivity as well as per acre or so productivity?

10) Can we do a cost benefit ratio? Input cost v/s output as incomes? - accounting for labour cost as well at the min wage rate for women (this is imp as women don't end up accounting for their labour cost which is a high input cost.

2. Ecological Sustainability

1) Has there been an improvement in the quality of soil that they have observed?

2) Seed collection and conservation activities and their contribution to ecological sustainability?

3) Has water usage for crop cultivation changed over the years? Improved with organic farming?

4) How has the use of bio-pesticides helped in improving ecological conditions for them?

\section{Decision Making}

1. Have they always been able to decide as what to grow?

2. Do they have autonomy over the incomes earned?

3. Do they decide the expenditure patterns of the income?

4. What are all the decisions that they are a part of in the house?

5. How do they see a change in themselves after engaging in this activity?

6. Do they recognize themselves as farmers?

7. Share stories about empowering experiences 


\section{REFERENCES}

[1] Dand S, Andharia J, Mamidipudi S. Empowering Women in Agriculture: Closing the Gender Gap through Mahila Kisan Sashaktikaran Pariyojana (MKSP). New Delhi: Access Development Services; 2015.

[2] Velayudhan M. Contextualising Women's Rights and Entitlements to Land: Insights from Gujarat. Social Change. 2012; 42(4):505-526.

[3] Scott J, Marshall G. Collective Action [Internet]. 4th ed. Dictionary of Sociology. Oxford University Press; 2009 [cited 24 January 2016]. Available from: http://www.oxfordreference.com/view/10.1093/acref/97801 99533008.001.0001/acref-9780199533008

[4] Vanni F. The Role of Collective Action. In: Vanni F, ed. by. Agriculture and Public Goods. Springer; 2018. p. 21-37.

[5] Uetake T. Managing Agri-Envirnonmental Commons through Collective Action: Lessons from OECD Countries. Commoners and the Changing Commons: Livelihoods, Environmental Security, and Shared Knowledge, the Fourteenth Biennial Conference of the International Association for the Study of the Commons. France; 2013.

[6] Baland J, Platteau J. Halting degradation of natural resources. New York, NY: Food and Agriculture Organization of the United Nations; 2007.

[7] Wade R. The management of common property resources: collective action as an alternative to privatisation or state regulation. Cambridge Journal of Economics. 1987; 11(2):95-106.

[8] Ostrom E. Governing the commons. Cambridge: Cambridge University Press; 1990.

[9] Agrawal A. Common Property Institutions and Sustainable Governance of Resources. World Development. 2001; 29(10):1649-1672.

[10] Agarwal B. Rethinking Agricultural Production Collectivities. Economic and Political Weekly. 2010; XLV (9):64-78.

[11] Women's empowerment in agriculture index [Internet]. INTERNATIONAL FOOD POLICY RESEARCH INSTITUTE (IFPRI); 2012 [cited 24 February 2016]. Available from:

http://www.ifpri.org/publication/womens-empowerment-ag riculture-index

[12] Rocheleau D, Thomas-Slayter B, Wangari E. Feminist political ecology. London: Routledge; 1996.

[13] Kothari A. Radical Ecological Democracy: A Path Forward for India and Beyond [Internet]. Greattransition.org. 2014 [cited 24 March 2016]. Available from: http://www.greattransition.org/publication/radical-ecologic al-democracy-a-path-forward-for-india-and-beyond

i The author would like extend gratitude to Society for Promoting Participatory Ecosystem Management (SOPPECOM), Pune for funding the study as a part of the author's dissertation work. The author is thankful
[14] About Us [Internet]. Womenscollective.net. 2018 [cited 24 February 2016]. Available from: http://womenscollective.net/about-us/

[15] Desor S, Nair V. Maati [Internet]. Pune: Kalpavriksh; 2014 [cited 24 February 2016]. Available from: http://kalpavriksh.org/images/alternatives/CaseStudies/Maa ti_Case\%20study\%20report_25April2014.pdf

[16] Deccan Development Society [Internet]. Ddsindia.com. 2006 [cited 24 January 2016]. Available from: http://ddsindia.com/www/default.asp

[17] Krook M. Are There Feminist Research Methods? [Internet]. Arizona: Arizona State University; 2007 [cited 12 January 2016]. Available from: http://mlkrook.org/pdf/Krook\%20FEMMSS2\%202007.pdf

[18] Whitehead T. Basic Classical Ethnographic Research Methods [Internet]. Maryland: Cultural Ecology of Health and Change; 2005 [cited 24 May 2016]. Available from: http://www.cusag.umd.edu/documents/workingpapers/class icalethnomethods.pdf

[19] Etikan I, Musa S, Alkassim R. Comparison of Convenience Sampling and Purposive Sampling. American Journal of Theoretical and Applied Statistics. 2016;5(1):1.

[20] Chen M, Jhabvala R, Kanbur R, Richards C. Membership Based Organizations of the Poor: Concepts, Experience and Policy. Ahmedabad; 2006.

[21] Bakshi R. Bazaars, Conversations and Freedom. New Delhi: Penguin; 2009.

[22] Kothari A. The Search for Radical Alternatives: Key Elements and Principles - Countercurrents [Internet]. Countercurrents. 2018 [cited 20 January 2016]. Available from:

https://countercurrents.org/2016/11/03/the-search-for-radic al-alternatives-key-elements-and-principles/

[23] Kothari A. Very Much on the Map: the Timbaktu Collective [Internet]. Vikalpsangam.org. 2014 [cited 24 January 2016]. Available from: http://www.vikalpsangam.org/static/media/uploads/Vikalp $\% 20$ Sangam $\% 20$ Case $\% 20$ Studies/timbaktu_collective_case study_ak.pdf

[24] Bourdieu P. The Forms of Capital. In: Richardson J, ed. by. Handbook of Theory and Research for the Sociology of Education. New York: Greenwood; 1986. p. 241-258.

[25] Polman N, Poppe J, Schans W. Nested markets with common pool resources in multifunctional agriculture. Rivista di Economia Agraria. 2010; 65(2):295-318.

[26] Wastelands: Types and Status in India [Internet]. Green Clean Guide. 2011 [cited 24 January 2018]. Available from: http://greencleanguide.com/wastelands-types-and-status-inindia/

to Seema Kulkarni of SOPPECOM for her continuous guidance and to Sneha Bhat of SOPPECOM for her support, professional and personal.

ii Currently, Roshan Rathod is a subject area specialist for institution building and gender at People's Science Institute, Dehradun. 